\title{
THE GERMAN SEPARATION BETWEEN POLICE AND THE OFFICES FOR THE PROTECTION OF THE CONSTITUTION. LEGAL FRAMEWORK
}

DOI:10.47743/rdc-2016-2-0002

Codrin TIMU, LL.M.

Research Assistant

Chair for Public Law - Administrative law

Prof. Dr., Dr. h.c. Martin IBLER

University of Konstanz, Germany

\section{Abstract}

"The rule of law and the federal state, as well as the protection of the fundamental rights could forbid the fusion of certain offices or the delegation of these offices with functions that are incompatible with their constitutional position ". In this manner the Federal Constitutional Court of Germany mentions the separation between police and the offices for the protection of the constitution. After the terrorist attacks in the USA, Spain, France, Belgium and Germany, the teamwork between the state offices has kept on intensifying. The discussion (debate) about the legal framework of the separation principle continued however to exist. In a time, where the security of the citizens steals away the space of the fundamental rights, to treat this subject is of the utmost importance ${ }^{2}$, in order not to allow the recurrence of the mistakes of the Weimar Republic. The article deals with the legal framework of the German separation between police and the offices for the protection of the constitution and gives an answer to the question if this principle has a constitutional status.

Keywords: the separation principle; police; offices for the protection of the constitution; the rule of law; proportionality principle; police law; constitutional law; terrorism

\section{The short history of the separation principle}

The history of the separation principle is relatively short and complex. The weaknesses of the Weimar Republic (the possibility of emergency regulations according to Article $48 \mathrm{WRV}^{3}$ or the lack of the $5 \%$ clause for the political parties in the Parliament)

\footnotetext{
${ }^{1}$ Decision of the Federal Constitutional Court of Germany - BVerfGE 97, 198, 217.

2 The article is based on the author LL.M. research and represents its results in a concentrated form.

${ }^{3}$ Constitution of the Weimar Republic - Die Verfassung des Deutschen Reiches, RGBl, p. 1383.
} 
The german separation between police and the offices for the protection...

have made easier the transformation of the police in an instrument of keeping and developing National Socialism 4 . The Allies have tried after the Second World War to build a new German state of law, that will prevent in the future such atrocities like the ones made by the secret German police (Geheime Staatspolizei - Gestapo) ${ }^{5}$. The so called "Polizeibrief" (Letter addressed to the Parliament of the Federal Republic of Germany by the Military Governors of the Allied Occupied Zones in the West, regarding the organization of the police) represents the starting point of the separation between police and the offices for the protection of the constitution:

"The Military Governors have come to the following agreement:

(...)

2. The Federal Government is allowed (...), to establish an office for the collection and the transmission of information regarding subversive activities directed against the Federal Government. This office should not have any competences of the police" 6 .

The content of the letter was also later reminded in point 3 of the Letter of Approval of the German Constitution by the three Western Allies ${ }^{7}$, letter which was sent on the $12^{\text {th }}$ of May 1949 to the President of the German Parliamentary Council (Adenauer). Since both acts represent occupation law, these ceased their effects in 1955, as the "Contract regarding Germany" was signed on $26^{\text {th }}$ of May $1952^{8}$, which proclaimed the Federal Republic of Germany as a sovereign state. The separation principle was later reminded in the $\S 3$ para. (3) of the Law regarding the Collaboration between the Federation and the States regarding matters for the protection of the constitution $^{9}$ and adjusted after the reunification of Germany in ordinary federal laws, state constitutions and ordinary state laws.

\section{The legal framework of the separation principle in the ordinary federal laws, in the state constitutions and in the ordinary state laws}

According to $\S 2$ para. (1) s. 3 BVerfSchG $^{10}$ the affiliation of a police office to the Federal Office for the protection of the Constitution is not permitted. Limitations of the collaboration regarding private data are to be found in $\S \S 19$ para. (1) and 20 para. (1)

\footnotetext{
${ }^{4}$ Dorn, Das Trennungsgebot in verfassungshistorischer Perspektive zur Aufnahme inlandsnachrichtendienstlicher Bundeskompetenzen in das Grundgesetz vom 23 Mai 1949, 2004, p. 47.

5 See Klee, Neue Instrumente der Zusammenarbeit von Polizei und Nachrichtendiensten. Geltung, Rang und Reichweite des Trennungsgebots, 2010, p. 21; Albert, Das "Trennungsgebot" - ein für Polizei und Verfassungsschutz überholtes Entwicklungskonzept?, ZRP 1995, 106.

${ }^{6}$ Huber, Quellen zum Staatsrecht der Neuzeit, Tübingen, 1951, p. 216.

7 The Official Journal of the Military Government - Germany (British Zone), Ausgabe no. 35, 10 September 1949, Teil 2B, S. $29 \mathrm{f}$.

${ }^{8}$ BGBl. II 1955, pp. 306-320.

${ }^{9}$ The Teamworklaw from 27 September 1950, BGBl. I 1950, p. 682.

10 Federal law regarding the protection of the constitution - Bundesverfassungsschutzgesetz from 20 December 1990 (BGBl. I, S. 2954, 2970), with its last modification through Article 1 of the Law from 17 November 2015 (BGBl. I, S. 1938)(BVerfSchG).
} 


\section{Codrin TIMU • Martin IBLER}

BVerfSchG. Similar legal norms regarding other forms of collaboration between offices are to be found in $\S 1$ para. (1) s. 2 BNDG $^{11}$ and in $\S 1$ para. (4) MADG ${ }^{12}$. Each of these limitations in the ordinary federal laws corresponds to a separation between police and the offices for the protection of the constitutions in four different ways: an organizational separation, a functional separation, an informational separation and a competency separation.

At the level of the states the separation principle has constitutional status in Sachsen, Thüringen and Brandenburg according to Article 83 para. (3) s. 1 SächsVerf ${ }^{13}$, Article 97 para. (2) ThürVerf ${ }^{14}$ and Article 11 para. (3) s. 2 BbgVerf ${ }^{15}$. All the other states settle the separation principle in ordinary laws. Some see to explicit regularize a specific type of separation and some not. For example, all the states regularize the informational and the competency separation. Berlin, Niedersachsen and Nordrhein-Westfalen do not expressively regularize an organizational separation. In a similar way, an explicit functional separation of the offices is only to be seen in Bremen, Nordrhein-Westfalen, Sachsen-Anhalt and Thüringen.

The easiest way to observe the differences of the regulation of the separation principle at the state level is through a tabular form:

\begin{tabular}{|c|c|c|c|c|}
\hline \multirow{2}{*}{ State } & \multicolumn{4}{|c|}{$\begin{array}{l}\text { The explicit regulation of the principle of separation between the police and } \\
\text { the offices for the protection of the constitution }\end{array}$} \\
\hline & $\begin{array}{l}\text { Competency } \\
\text { separation }\end{array}$ & $\begin{array}{c}\text { Organizational } \\
\text { separation }\end{array}$ & $\begin{array}{l}\text { Functional } \\
\text { separation }\end{array}$ & $\begin{array}{c}\text { Informational } \\
\text { separation }\end{array}$ \\
\hline $\begin{array}{l}\text { Baden- } \\
\text { Württemberg }\end{array}$ & $\begin{array}{l}\S 5 \text { para. (3) s. } 1 \\
\text { LVSG BW } 16\end{array}$ & $\begin{array}{l}\text { § } 2 \text { para. (3) } \\
\text { LSVG BW }\end{array}$ & - & $\begin{array}{l}\S \S 6,9,10 \text { LSVG } \\
\text { BW }\end{array}$ \\
\hline Bayern & $\begin{array}{l}\S 1 \text { para. (4) s. } 3 \\
\text { BayVSG }^{17}\end{array}$ & $\begin{array}{l}\S 1 \text { para. (4) s. } 2 \\
\text { BayVSG }\end{array}$ & - & $\S \S 12-17$ BayVSG \\
\hline
\end{tabular}

11 Federal law regarding the federal information service - BND-Gesetz from 20 December 1990 (BGBl. I, S. 2954, 2979), with its last modification through Article 3 of the Law from 17 November 2015 (BGBl. I, S. 1938)(BNDG).

12 Federal law regarding the military counter-espionage service - MAD-Gesetz from 20 December 1990 (BGBl. I, S. 2954, 2977), with its last modification through Article 2 of the Law from 17 November 2015 (BGBl. I, S. 1938)(MADG).

13 Constitution of Sachsen - Verfassung des Freistaates Sachsen, SächsGVBl. 1992, 243, with its last modification through the Law from July 2013 (SächsGVBl, S. 502).

${ }_{14}$ Constitution of Thüringen - Verfassung des Freistaates Thüringen, GVBl. 1993, 625, with its last modification through the Law from 11 October 2004 (GVBl, S. 745).

15 Constitution of Brandenburg - Verfassung des Freistaates Brandenburg, GVBl. I 1992, 298, with its last modification through the Law from 18 March 2015 (GVBl. I no. 6).

16 Law regarding the protection of the constitution in Baden-Württemberg - Gesetz über den Verfassungsschutz in Baden-Württemberg, GBl. 2006, 1, with its last modification through Article 1 of the Law from 21 July 2015 (GBl, S. 642).

17 Law regarding the protection of the Constitution in Bayern - Bayerisches Verfassungsschutzgesetz, GVBl 1997, S. 70, with its last modification through $§ 1$ no. 15 of the Government Decision from 22 July 2014 (GVBl, S. 286). 
The german separation between police and the offices for the protection...

\begin{tabular}{|c|c|c|c|c|}
\hline Berlin & $\begin{array}{l}\text { § } 8 \text { para. (7) VSG } \\
\mathrm{Bln}^{18}\end{array}$ & - & - & $\begin{array}{l}\S \S 21,22,27 \text { VSG } \\
\text { Bln }\end{array}$ \\
\hline Brandenburg & $\begin{array}{l}\S 6 \text { para. (4) } \\
\text { BbgVerfSchG }^{19}\end{array}$ & $\begin{array}{l}\S 2 \text { para. (2) } \\
\text { BbgVerfSchG }\end{array}$ & - & $\begin{array}{l}\S \S 12,14,17 \\
\text { BbgVerfSchG }\end{array}$ \\
\hline Bremen & $\begin{array}{l}\S 6 \text { para. (4) } \\
\text { BremVerfSchG }{ }^{20}\end{array}$ & $\begin{array}{l}\S 2 \text { para. (1) s. } 3 \\
\text { BremVerfSchG }\end{array}$ & $\begin{array}{l}\S 2 \text { para. (1) s. } 3 \\
\text { BremVerfSchG }\end{array}$ & $\begin{array}{l}\S \S 18,21 \\
\text { BremVerfSchG }\end{array}$ \\
\hline Hamburg & $\begin{array}{l}\S 2 \text { para. (2) } \\
\text { HmbVerfSchG }{ }^{21}\end{array}$ & $\begin{array}{l}\S 2 \text { para. (2) } \\
\text { HmbVerfSchG }\end{array}$ & - & $\begin{array}{l}\S \S 12,14,19 \\
\text { HmbVerfSchG }\end{array}$ \\
\hline Hessen & $\begin{array}{l}\S 3 \text { para. (4) } \\
\text { VerfSchutzG HE } \mathrm{HE}^{22}\end{array}$ & $\begin{array}{l}\S 1 \text { para. (1) } \\
\text { VerfSchutzG HE }\end{array}$ & - & $\begin{array}{l}\S \S 8,10,11 \\
\text { VerfSchutzG HE }\end{array}$ \\
\hline $\begin{array}{l}\text { Mecklenburg- } \\
\text { Vorpommern }\end{array}$ & $\begin{array}{l}\S 8 \text { LVerfSchG } \\
M-V^{23}\end{array}$ & $\begin{array}{l}\S 2 \text { LVerfSchG } \\
M-V\end{array}$ & - & $\begin{array}{l}\S \S 20,24 \\
\text { LVerfSchG M-V }\end{array}$ \\
\hline Niedersachsen & $\begin{array}{l}\S 5 \text { para. (4) } \\
\text { NVerfSchG }{ }^{24}\end{array}$ & - & - & $\begin{array}{l}\S \S 15,18 \\
\text { NVerfSchG }\end{array}$ \\
\hline
\end{tabular}

${ }^{18}$ Law regarding the protection of the Constitution in Berlin - Gesetz über den Verfassungsschutz in Berlin, GVBl, S. 235, with its last modification through: $\S \S 33$ and 36 modified through the Law from 1 December 2010 (GVBl, S. 534).

${ }^{19}$ Law regarding the protection of the Constitution in Brandenburg - Gesetz über den Verfassungsschutz im Land Brandenburg, GVBl. I 1993, S.78, with its last modification through: § 24 through the Law from 17 December 2014 (GVBl. I no. 44).

${ }^{20}$ Law regarding the protection of the Constitution in Bremen - Gesetz über den Verfassungsschutz im Lande Bremen, Brem.GBl. 2013, S. 769, with its last modification through: Amendament from 25 March 2014 (Brem.GBl, S. 228).

${ }^{21}$ Law regarding the protection of the constitution in Hamburg - Hamburgisches Verfassungsschutzgesetz, HmbGVBl. 1995, S. 45, with its last modification through: §§ 1 and 7 modified şi § 7c newly inserted through Article 3 of the Law from 19 June 2013 (HmbGVBl, S. 293).

22 Law regarding the protection of the constitution in Hessen - Gesetz über das Landesamt für Verfassungsschutz, Hessen, GVBl. I, S. 753, with its last modification through Article 2 from 27 June 2013 (GVBl, S. 444).

${ }^{23}$ Law regarding the protection of the Constitution in Mecklenburg-Vorpommern - Gesetz über den Verfassungsschutz im Lande Mecklenburg-Vorpommern, GVOBl, M-V 2001, S. 261, with its last modification through Article 1 of the Law from 25 April 2016 (GVOBl. M-V, S. 203).

${ }^{24}$ Law regarding the protection of the Constitution in Niedersachsen - Gesetz über den Verfassungsschutz im Lande Niedersachsen, Nds. GVBl, 2009, S.154, with its last modification through: $\S \S 5$ a and 5 b modified, $\S 5$ c newly inserted through Article 2 and $\S 5$ out of effect through Article 6 of the Law from 19 June 2013 (Nds. GVBl, S. 158) - Article 7 of the Law from 19 June 2013 modified through the Law from 3 June 2015 (Nds. GVBl, S. 99) - Article 6 and Article 7 s. 2 of the Law from 19 June 2013 (Nds. GVBl, S. 158; 2015, S. 99) out of effect through the Law from 8 June 2016 (Nds. GVBl, S. 115).

STUDIES AND ARTICLES 


\begin{tabular}{|c|c|c|c|c|}
\hline $\begin{array}{l}\text { Nordrhein- } \\
\text { Westfalen }\end{array}$ & $\begin{array}{l}\S 5 \text { para. (9) VSG } \\
\text { NRW }^{25}\end{array}$ & - & $\begin{array}{l}\S 2 \text { para. (1) s. } \\
2 \text { VSG NRW }\end{array}$ & $\begin{array}{l}\S \S 16,18 \text { VSG } \\
\text { NRW }\end{array}$ \\
\hline Rheinland-Pfalz & $\begin{array}{l}\text { § 8 para. (3) } \\
\text { LVerfSchG RP } 26\end{array}$ & $\begin{array}{l}\S 2 \text { para. (2) } \\
\text { LVerfSchG RP }\end{array}$ & - & $\S 14$ LVerfSchG RP \\
\hline Saarland & $\begin{array}{l}\S 3 \text { para. (3) } \\
\text { SVerfSchG }{ }^{27}\end{array}$ & $\begin{array}{l}\text { § } 2 \text { para. (2) s. } 2 \\
\text { SVerfSchG }\end{array}$ & - & $\begin{array}{l}\S \S 15,17 \\
\text { SVerfSchG }\end{array}$ \\
\hline Sachsen & $\begin{array}{l}\text { § } 4 \text { para. (3) } \\
\text { SächsVSG }\end{array}$ & $\begin{array}{l}\text { § } 1 \text { para. (4) } \\
\text { SächsVSG }\end{array}$ & - & $\begin{array}{l}\S \S 10,12 \\
\text { SächsVSG }\end{array}$ \\
\hline Sachsen-Anhalt & $\begin{array}{l}\S 7 \text { para. (5) } \\
\text { VerfSchG-LSA }\end{array}$ & $\begin{array}{l}\S 2 \text { para. (2) } \\
\text { VerfSchG-LSA }\end{array}$ & $\begin{array}{l}\S 2 \text { para. (2) } \\
\text { VerfSchG-LSA }\end{array}$ & $\begin{array}{l}\S \S 17,19 \\
\text { VerfSchG-LSA }\end{array}$ \\
\hline Schleswig-Holstein & $\begin{array}{l}\S 9 \text { LVerfSchG } \\
\text { S-H }\end{array}$ & $\begin{array}{l}\S 2 \text { para. (2) } \\
\text { LVerfSchG S-H }\end{array}$ & - & $\begin{array}{l}\S \S 19,23 \\
\text { LVerfSchG S-H }\end{array}$ \\
\hline Thüringen & $\begin{array}{l}\S 2 \text { para. (2) } \\
\text { ThürVerfSchG }{ }^{31}\end{array}$ & $\begin{array}{l}\S 7 \text { para. (2) } \\
\text { ThürVerfSchG }\end{array}$ & $\begin{array}{l}\S 2 \text { para. (2) } \\
\text { ThürVerfSchG }\end{array}$ & $\begin{array}{l}\S \S 11,14,21 \\
\text { ThürVerfSchG }\end{array}$ \\
\hline
\end{tabular}

In European law until now there hasn't taken place any explicit regulation of a separation between police and the domestic intelligence services (offices for the protection of the constitution). One cannot talk about a flaw on this level, since the separation principle is and remains in its origin a national principle of Germany due to its history.

25 Law regarding the protection of the Constitution in Nordrhein-Westfalen - Gesetz über den Verfassungsschutz in Nordrhein-Westfalen, GV. NRW, 1995, S. 28, with its last modification through: more times modified through Article 1 of the Law from 21 June 2013 (GV. NRW, S. 367).

${ }^{26}$ Law regarding the protection of the Constitution in Rheinland-Pfalz - Landesverfassungsschutzgesetz, Rheinland-Pfalz, GVBl, 1998, S. 184, with its last modification through: more times modified through Article 3 of the Law from 22 December2015 (GVBl, S. 461).

27 Law regarding the protection of the Constitution in Saarland - Gesetz no. 1309 - Saarländisches Verfassungsschutzgesetz, Amtsblatt 1993, S. 296, with its last modification through: more times modified through Article 1 of the Law from 12 November 2014 (Amtsbl. I, S. 1462).

${ }^{28}$ Law regarding the protection of the Constitution in Sachsen - Gesetz über den Verfassungsschutz im Freistaat Sachsen, SächsGVBl. 1992, S. 459, with its last modification through Article 3 of the Law from 17 December 2013 (SächsGVBl, S. 890, 891).

${ }^{29}$ Law regarding the protection of the Constitution in Sachsen-Anhalt - Gesetz über den Verfassungsschutz im Land Sachsen-Anhalt, GVBl. LSA 2006, 236, with its last modification through: Contents, §§ 11, 12 modified, $\S 30$ newly inserted through Article 3 of the Law from 3 July 2015 (GVBl. LSA, S. 314, 317).

${ }^{30}$ Law regarding the protection of the Constitution in Schleswig-Holstein - Gesetz über den Verfassungsschutz im Lande Schleswig-Holstein, GVOBl, 1991, 203, with its last modification through: replace of the definition of competences (Article 8 LVO v. 16 March 2015, GVOBl, S. 96).

31 Law regarding the protection of the Constitution in Thüringen - Thüringer Gesetz zum Schutz der freiheitlichen demokratischen Grundordnung und zur Vorbeugung vor Gefahren für die freiheitliche demokratische Grundordnung (Thüringer Verfassungsschutzgesetz), GVBl, 2014, 529. 


\section{The german separation between police and the offices for the protection...}

\section{The legal framework of the separation principle}

\section{in the federal constitutional law}

The central problem regarding the separation principle is if there is a legal framework in the German constitution. A clear answer to this question can make a huge difference for the legislator, a difference with a specific importance in these times overwhelmed by terrorist attacks. If the separation principle would have a legal framework in the German constitution, then the legislator would have to respect the coordinates of Article $79 \mathrm{GG}^{32}$, if it desires the modification or the removal of the separation.

The key-articles in the German constitution that could give the separation principle a constitutional status are Article 73 para. (1) no. 10 GG and Article 87 para. (1) s. 2 GG. However, from a teleological, systematical and grammatical interpretation of the articles does not result any legal framework of a separation principle. The constitutional legislator could have foreseen an organizational and competency separation between police and the offices for the protection of the constitution; however, the primary objective of Article 73 para. (1) no. $10 \mathrm{GG}$ is the regulation of the exclusive legislative competences of the Federation and the aim of Article 87 para. (1) s. 2 GG is the authorization of the federal legislator to establish these offices. Not even with the historical interpretation of the Article 73 para. (1) no. 10 and Article 87 para. (1) s. 2, interpretation which was heavily researched by Dorn, one cannot deduce a constitutional status of the separation principle ${ }^{33}$.

Nevertheless, after the numerous terror attacks the efficiency of the defense against international terrorism is being put more and more under question and not just regarding the protection of the constitution. The protection of the fundamental rights, the rule of law and the federal principle need a certain proportionality to the protection of the constitution, a proportionality that can be described as "very sensitive". In this view the Federal Constitutional Court of Germany deduced many times an informational separation from the depths of the rule of law, which demands specific requirements for the collaboration between the organs of the State ${ }^{34}$.

What about the other kinds of separation: the organizational, the functional and the competency ones? The history of the German Constitution and of the German rule of law determines a certain individuality of this country. "There is a traditional context,

\footnotetext{
${ }^{32}$ Constitution of Germany - Grundgesetz für die Bundesrepublik Deutschland in der im Bundesgesetzblatt Teil III, Gliederungsnummer 100-1, veröffentlichten bereinigten Fassung, with its last modification through Article 1 of the Law from 23 December 2014 (BGBl. I, S. 2438).

${ }_{33}$ Dorn, Das Trennungsgebot in verfassungshistorischer Perspektive zur Aufnahme inlandsnachrichtendienstlicher Bundeskompetenzen in das Grundgesetz vom 23 Mai 1949, 2004, p. 193 f.

${ }^{34}$ Decision of the Federal Constitutional Court of Germany - BVerfGE 133, 277, 329. See also BVerfG, Urteil vom 20 April 2016 - 1 BvR 966/09, 1 BvR 1140/09 -, juris.
} 


\section{Codrin TIMU • Martin IBLER}

which indicates that the rule of law, beyond any law dogmatic, means experience, conscience and life" ${ }^{\prime 35}$. There are no exact definitions and limited descriptions of the rule of law when we are referring ourselves on a national level. Along the general subprinciples, such as the certainty of the law or the separation of powers, the rule of law comprises also specific national elements that individualize it and that are not to be found in the other states. In France there is the talk about "État de droit" and in Great Britain about "the rule of law" - both are different from the German rule of law (Rechtsstaatsprinzip) because of the different historical experiences ${ }^{36}$. In the same way the market economy and the private property could be specific elements of the rule of law in the countries in Eastern Europe, for the simple reason of the ceased existence of the socialist systems. Regarding Germany, only the terminological argument, the fact that "Rechtsstaat" does not have any exact translation in another language, proves the specificity of the German rule of law"

Since every rule of law has its own individuality and because of the legal norms in the German occupational law after the Second World War, the separation between police and the offices for the protection of the constitution has a special meaning. As already mentioned, one of the most important ideas by the creation of the actual German constitution is to prevent another terror-regime as the one that was under the Gestapo. In the German constitution there are numerous legal norms with the sole purpose to prevent happenings like those that occurred between the years 1933-1945, for example "the eternity clause" [Article 79 para. (3) GG] or the right to resistance from Article 20 para. (4) GG ${ }^{38}$. As long as Germany didn't adopt a new constitution after the reunification, one cannot deny the history of the actual German constitution and the individuality of the German rule of law, especially as key elements for the interpretation of the constitutional norms.

A separation between police and the offices for the protection of the constitution can be seen as a concretization of the principle of proportionality - the separation is necessary in order to restrict the exercise of state power and to strengthen the constitutional prohibition of state excesses ${ }^{39}$. Taking this as a basis, one can say that many law aspects could have constitutional status, if they would be seen as concretizations of the principle of proportionality. Thanks to its development history and its unicity, the separation principle is one of them. The history of the German

35 Schmidt-Aßmann, in: Isensee/Kirchhof, Handbuch des Staatsrechts der Bundesrepublik Deutschland,

3. Auflage, Band II, 2003, §26, Rn. 10.

${ }^{36}$ Ibidem, Rn. 101.

37 Stern, Der Staat des Grundgesetzes, 1992, p. 3.

38 Klee, Neue Instrumente der Zusammenarbeit von Polizei und Nachrichtendiensten. Geltung, Rang und Reichweite des Trennungsgebots, 2010, p. 57.

39 Stubenrauch, Gemeinsame Verbunddateien von Polizei und Nachrichtendiensten. Eine verfassungsrechtliche Untersuchung am Beispiel der Antiterrordatei, 2009, p. 36. 
The german separation between police and the offices for the protection...

constitution and the individuality of the German rule of law offer the separation principle a constitutional status.

As a conclusion, the national particularity of the German rule of law determines the development of the definition of the separation principle: it is a specific element of the German rule of law, through which it is forbidden the affiliation of the police to the offices for the protection of the constitution on the federal level, as well as on the state level. Along these lines the separation principle must not be seen as an opposition to the effective fulfilment of the state obligation to guarantee security and human rights, but as a harmonizing element of the constitutional order of the rule of law. 